УДК 621.791.75.01

Коваленко В. Л., Мастенко Р. В., Стреленко Н. М., Зворикін К. О.

Національний технічний університет України «Київський політехнічний інститут імені Ігоря Сікорського». Україна, м. Київ

\title{
УДОСКОНАЛЕННЯ КРИТЕРІЮ ОЦІНКИ СТАБІЛЬНОСТІ ІСНУВАННЯ ДУГОВОГО РОЗРЯДУ НА ПОСТІЙНОМУ СТРУМІ
}

\begin{abstract}
Розглядаеться проблема визначення стабільності горіння дуги при використанні постійного струму. Створено методику для проведення комп'ютерного осцилографування енергетичних параметрів зварювального дугового розряду. Розроблено програмне забезпечення для аналізу отриманих осцилограм. Розроблено критерій визначення стабільності існування зварювального дугового розряду. [dx.doi.org/10.29010/080.7]
\end{abstract}

Ключові слова: зварювання; стабільність горіння зварювальної дуги; зварювальний дуговий розряд; критерій.

Однією з важливих характеристик дугового розряду є стабільність його існування у специфічних умовах зварювання. Вона безпосередньо впливає на перенос електродного металу, гідродинамічні умови у зварювальній ванні і, як наслідок, на якість формування металу шва та хімічний склад [1]. Проведений аналіз відомих способів та методик оцінювання стабільності зварювального дугового розряду при використанні постійного струму показав, що єдиної комплексної методики оцінювання, яка б враховувала фізичні особливості його існування та технологічні властивості, немає [2].

Неоднозначними є дані стосовно впливу перехідних процесів на стабільність існування зварювального дугового розряду. Ці процеси можуть визначатися за формою осцилограм, які ілюструють весь процес горіння дуги, від етапу ії запалювання і до етапу розриву [3].

Актуальним є розроблення методики комп'ютерного осцилографування енергетичних параметрів зварювального дугового розряду з точністю, яка $€$ необхідною для дослідження перехідних процесів в зварювальній дузі.

Для проведення комп'ютерного осцилографування енергетичних параметрів зварювального дугового розряду було використане схема, яка зображена на рисунку 1 [4].

Запропонована схема дозволяє фіксувати зміну енергетичних параметрів зварювального дугового розряду у процесі його існування і через аналогоцифровий перетворювач (АЦП) передавати ці дані на персональний комп'ютер, де проводиться їх подальший аналіз та оброблення.

В реальному процесі зварювання енергетичні параметри змінюються в досить великих межах, що можна спостерігати при детальному розгляді осцилограм (рис. 2).

Оскільки всі дані, записані аналого-цифровим перетворювачем, є хоч і дискретними, але ця дискретність має надзвичайно маленьке значення та не впливає на загальну картину. Це дозволяє не тільки проводити візуальну оцінку отриманих енергетичних параметрів зварювального дугового розряду, але і проводити необхідні розрахунки для визначення стабільності його існування, а також здійснювати визначення кількості та амплітудні значення піків напруги та струму на осцилограмах, які дають інформацію про перенос металу, а також зміну розташування анодної та катодної плям.

Після проведення зварювання був отриманий масив даних, який включає в себе значення струму та напруги в кожен момент часу. Для визначення стабільності були важливі критичні значення струму та напруги, які випадають 3 нормальних, середніх значень режиму зварювання, коли дуга з якихось причин припиняла своє існування чи змінювала свою довжину. На осцилограмах ці критичні значення струму видно у вигляді «піків». На жаль, для ix виявлення не можна використовувати звичні методи 3 теорії ймовірності, такі як дисперсія випадкової величини чи середнє квадратичне відхилення, оскільки масив отриманих даних струму та напруги не являється нормальним розподілом. Тобто окрім тих критичних значень струму та напруги, які б могли вважатись випадковими, є i в принципі зміщення через те, що під час горіння дуги змінюється ії довжина, змінюється швидкість плавлення електроду, існує неоднорідність основного металу та багато інших факторів, які в сукупності у кожен момент часу міняють умови, в яких 


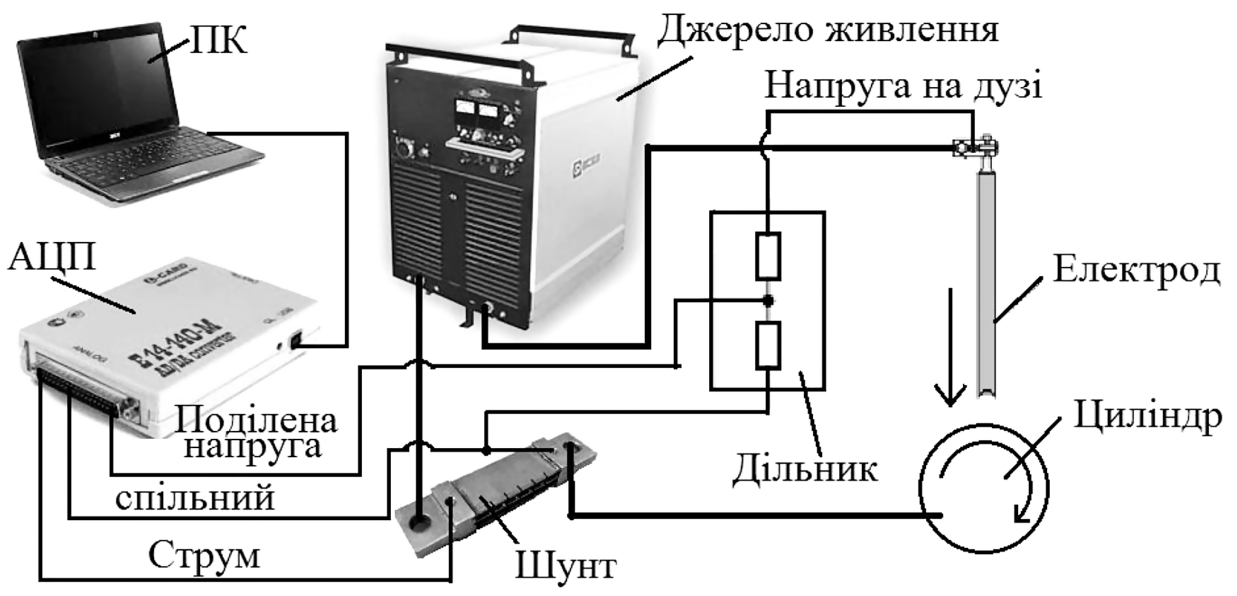

Рис. 1. Схема проведення комп'ютерного осцилографування

горить дуга. Це означає те, що під час зварювання є ділянки, в яких величини струму та напруги стабільно нижчі чи стабільно вищі. Тому, якщо пробувати проаналізувати масиви даних за формулами для нормального розподілу, то в результаті будуть отримані не коректні значення. Цікавить, як часто та наскільки суттєво відбуваються відхилення критичних значень енергетичних параметрів, оскільки саме вони і характеризують стабільність горіння зварювального дугового розряду. Для визначення цих критичних значень беруться $0,1 \%$ мінімальних показників і знаходиться середнє значення серед них. Ці середні значення врахують лише критичні значення піків, що і потрібно.

Стабільність дугового розряду пропонуєтьсявиражати за допомогою певного числового коефіцієнта, який враховує наступні параметри: відхилення струму та напруги у процесі існування зварювального дугового розряду та їх амплітудні значення.

$$
K_{\text {ст2 }}=\frac{\sum(0,1 \% \operatorname{In}) \times \sum(0,1 \% U n)}{\sum(I n) \sum(U n)},
$$

де $K_{\text {ст2}}-$ удосконалений коефіцієнт стабільності існування дугового розряду;

$\sum(0,1 \%$ In $)$ - сума $0,1 \%$ мінімальних значень струму;

$\sum(0,1 \% U n)$ - сума $0,1 \%$ мінімальних значень напруги;

$\sum(I n)$ - сума значень струму;

$\sum(U n)$ - сума значень напруги.

В умовах стабільного існування дугового розряду удосконалений коефіцієнт має наближається до одиниці, тому для реальних матеріалів, чим ближче він до одиниці, тим краща стабільність існування зварювального дугового розряду.

\section{Висновки}

На основі принципів комп'ютерного осцилографування була створена методика аналізу осцилографування енергетичних параметрів зварювальної дуги на постійному струмі. Показано, що використання аналого-цифрового перетворювача у зв'язці

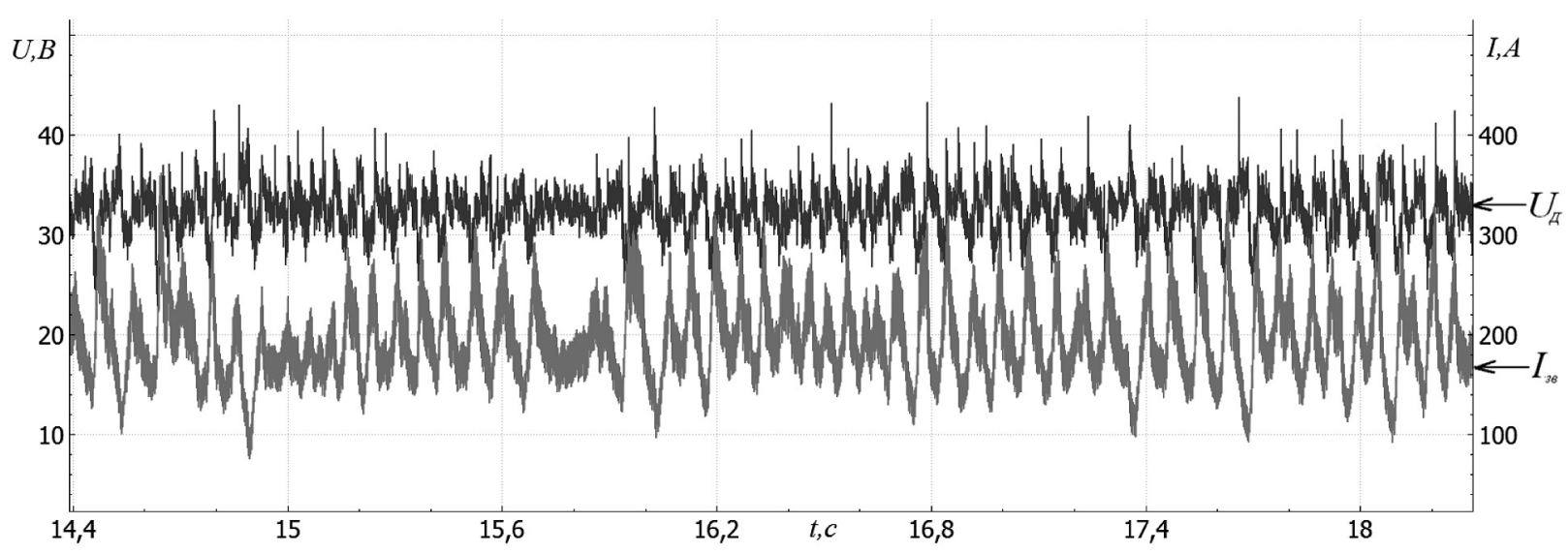

Рис. 2. Осцилограма енергетичних параметрів при використанні постійного струму 
3 персональним комп'ютером, надає можливість автоматично записувати осцилограми енергетичних параметрів дуги та обчислювати вдосконалений коефіцієнт стабільності, який дозволяє на новому, якісному рівні давати оцінку якосте зварювальних матеріалів та визначати їх придатність для подальшого використання.Наведений удосконалений коефіцієнт стабільності існування дугового розряду дозволяє більш адекватно кількісно оцінювати процес існування дугового розряду.

\section{Лiтература}

[1] Походня И. К., Явдощин И. Р., Пальцевич А. П., Швачко В. И., Котельчук А. С. Металлургия дуговой сварки. - К.: Наукова думка, 2004. - 440 с.
[2] Жданов Л. А., Коваленко В. Л., Коваленко Г. Л. Аналіз існуючих методик експериментальної оцінки стабільності існування дугового розряду при зварюванні. // Матеріали другої міжнародної міжгалузевої науково-технічної конференції студентів, аспірантів та наукових співробітників «Зварювання та споріднені технології і процеси»./ Київ: 4-6 березня 2009 p., c. $28-30$.

[3] Zhang Y. M. Real-Time Weld Process Monitoring, 2008,300 c.

[4] Жданов Л. А., Коваленко В. Л., Зворыкин К. О. Измерительный комплекс для фиксации электрических параметров сварки на переменном токе. Технологические системы. - 2005. - № 4. - с. 40-45.

Kovalenko V. L., Mastenko R. V., Strelenko N. M., Zvorykin C. O.

National Technical University of Ukraine «Igor Sikorsky Kiev Polytechnic Institute». Ukraine, Kiev

\author{
IMPROVEMENT OF THE CRITERION FOR ESTIMATING THE STABILITY \\ OF THE EXISTENCE OF AN ARC DISCHARGE ON A DIRECT CURRENT
}

The problem of determining the stability of arc combustion with the use of direct current is considered. The technique for computer oscillography of the energy parameters of the welding arc discharge is developed. The software for the analysis of the received oscillograms is developed. The criterion for determining the stability of the existence of a welding arc discharge is developed. [dx.doi.org/10.29010/080.7]

Keywords: welding; burning stability of the welding arc; welding arc discharge; criterion.

\title{
References
}

[1] Pokhodnja I. K., Javdoshhin I. R., Pal'cevich A. P., Shvachko V. I., Kotel'chuk A. S. Metallurgija dugovoj svarki. - K.: Naukova dumka, 2004. - 440 p.

[2] Zhdanov L. A., Kovalenko V. L., Kovalenko G. L. Analiz isnujuchih metodik eksperimental'noï ocinki stabil'nosti isnuvannja dugovogo rozrjadu pri zvarjuvanni. // Materiali drugoï mizhnarodnoï mizhgaluzevoï naukovo-tehnichnoï konferenciï studentiv, aspirantiv ta naukovih spivrobitnikiv «Zvarjuvannja ta sporidneni tehnologiï i procesi». / Kiev: 4-6 bereznja 2009, pp. 28-30.

[3] Zhang Y. M. Real-Time Weld Process Monitoring, 2008, 300 p.

[4] Zhdanov L. A., Kovalenko V. L., Zvorykin C. O. Izmeritelnyj complex dlja fiksacii elektricheskih parametrov svarki na peremennom toke. - Technological systems. - 2005. - № 4. - p. 40-45. 